\title{
ANALISA KELAYAKAN USAHATANI SEMANGKA NON BIJI DI DESA SUMBEREJO KECAMATAN BANYUPUTIH KABUPATEN SITUBONDO
}

\author{
Lukman'), Gema Iftitah Anugerah Yekti2*) \\ Program Studi Agribisnis, Fakultas Pertanian, Universitas Abdurachman Saleh Situbondo \\ Email Korespondensi : gema_iftitah@unars.ac.id
}

\begin{abstract}
Abstrak
Tujuan penelitian adalah untuk mengetahui besar pendapatan usahatani semangka non biji di Desa Sumberejo, mengetahui tingkat efisiensi usahatani semangka non biji di Desa Sumberejo dan mengetahui tingkat kelayakan usahatani semangka non biji di Desa Sumberejo Kecamatan Banyuputih. Populasi dalam penelitian ini adalah seluruh petani semangka non biji di di Desa Sumberejo Kecamatan Banyuputih yang berjumlah 28 orang, penarikan sampel menggunakan teknik sampel secara sensus atau sampling jenuh, yaitu pengambilan populasi untuk dijadikan sampel sehingga sampel yang diteliti adalah sebanyak 28 petani semangka non biji. Hasil penelitian menunjukkan bahwa pendapatan rata-rata usahatani semangka non biji menguntungkan, dimana pendapatan rata-rata mencapai Rp. 56.727.128,-. Efisiensi usahatani semangka non biji rata-rata efisien mencapai 3,93. Kelayakan untuk usahatani semangka non biji rata-rata layak untuk dikembangkan mencapai 3,93. Saran dari peneliti adalah petani harus berusaha mempertahankan bahkan meningkatkan usahatani semangka non biji karena memiliki prospek yang baik dan menguntungkan selama ini, menambah informasi mengenai teknis budidaya yang lebih modern, dan lebih memperhatikan manajemen budidaya semangka non biji
\end{abstract}

Kata Kunci : Kelayakan, Usahatani, Semangka Non Biji

\begin{abstract}
The purpose of this study was to determine the income, to find out the level of efficiency, and to determine the feasibility of non-seed watermelon farming in Sumberejo Village,Banyuputih Subdistrict. The population in this study was all non-seed watermelon farmers in Sumberejo Village, Banyuputih Subdistrict, 28 people. The sampling technique used sample census or saturated sampling techniques, that was population sampling to be sampled so that the samples studied were 28 non-seed watermelon farmers. The result showed that the average income of non-seed watermelon farming was profitable, where the average income reached Rp.56,727,128,-. The average efficiency of non-seed watermelon farming was 3.93. The feasibility for farming non-seed watermelon on average was feasible to develop, reaching 3.93. Some suggestions from the researcherwere that farmers should try to maintain and even increase non-seed watermelon farming because they have good and profitable prospects, add information about more modern cultivation techniques, and pay more attention to the management of non-seed watermelon cultivation.
\end{abstract}

Keywords: feasibility, farming, non-seed watermelon 


\section{PENDAHULUAN}

Pengembangan sektor pertanian di Indonesia menjadi salah satu agenda utama dari pembangunan yang berkelanjutan. Sektor pertanian menempati posisi yang strategis dalam struktur perekonomian Indonesia. Beberapa alasan yang mendasari pentingnya pertanian di Indonesia adalah potensi sumberdayanya yang besar dan beragam, pangsa terhadap pendapatan nasional cukup besar, besarnya penduduk yang menggantungkan hidupnya pada sektor ini, dan menjadi basis pertumbuhan di pedesaan (Moehar, 2002).

Sektor pertanian mampu menyediakan bahan pangan, bahan baku industri, meningkatkan devisa negara, menciptakan lapangan pekerjaan dan meningkatkan pendapatan masyarakat. Sasaran pembangunan pertanian saat ini lebih ditekankan pada ketahanan pangan dan pengembangan agribisnis (Dumairy, 2007).

Subsektor hortikultura diharapkan dapat memberikan kontribusi yang optimal guna meningkatkan kesempatan kerja, sehingga mampu mengurangi tingkat pengangguran. Perluasan kesempatan kerja bagi masyarakat, sebagai salah satu langkah guna meningkatkan pendapatan dan kesejahteraan masyarakat. Perluasan kesempatan kerja tersebut memiliki prospek yang cukup baik dalam membantu mempertahankan keberlanjutan produksi dan usahatani komoditas hortikultura (Anonim, 2017).

Masyarakat Indonesia yang bergerak di sektor pertanian sebagian besar bermukim di pedesaan dengan tingkat pendapatan yang masih rendah, oleh karena itu diperlukan upaya untuk lebih meningkatkan kesejahteraan petani antara lain dengan melakukan program diversifikasi pertanian. Kegiatan ini antara lain dapat diperoleh dengan usahatani budidaya tanaman semangka non biji yang mempunyai daya jual tinggi dengan cara pemeliharaan yang tidak rumit

Produk pertanian memiliki kekhasan dibanding dengan produk-produk lainnya, seperti mudah rusak (perishable), ukuran produk pertanian yang besar dan memakan tempat penyimpanan yang luas (bulky/voluminous) serta produksi yang bersifat musiman (gestation periode) (Soetriono, 2006). Semangka non biji merupakan salah satu tanaman hortikultura. Semangka non biji yang digemari masyarakat karena rasanya yang manis, renyah dan kandungan airnya yang banyak serta tanpa adanya biji didalamnya.

Semangka non biji termasuk salah satu jenis tanaman buah-buahan semusim yang mempunyai arti penting bagi perkembangan sosial ekonomi rumah tangga maupun negara. Daya tarik semangka non biji bagi petani terletak pada nilai ekonomisnya yang tertinggi, beberapa kelebihan usahatani semangka non biji diantaranya adalah berumur relatif singkat (genjah) sekitar 70-85 hari, dapat dijadikan tanaman penyelang dilahan sawah pada musim kemarau (Prajnanta, 2001). Pengembangan budidaya komoditas semangka non biji mempunyai prospek yang cerah karena dapat mendukung upaya peningkatan pendapatan petani, pengentasan kemiskinan, perbaikan gizi dan perluasan kesempatan kerja.

Kabupaten Situbondo merupakan daerah yang mempunyai temperatur rata-rata berkisar $24,7^{\circ} \mathrm{C}-27,9^{\circ} \mathrm{C}$ dengan rata-rata curah hujan antara $994-1.503 \mathrm{~mm}$ per tahunnya sehingga daerah ini menurut Klasifikasi Iklim Schmidt dan Fergusson tergolong daerah kering (Anonim, 2016). Kabupaten Situbondo berada pada ketinggian antara 0 $1.250 \mathrm{~m}$ di atas permukaan laut sehingga cocok untuk melakukan kegiatan budidaya tanaman semangka. Bila di lihat di lapangan, daerah Situbondo semakin banyak dilakukan usahatani semangka oleh petani. 
Berdasarkan data dari Dinas Pertanian Kabupaten Situbondo Tahun 2016 produksi semangka adalah sebagai berikut :

Tabel 1. Produksi Semangka Di Kabupaten Situbondo

\begin{tabular}{ccc}
\hline No & Semangka/Tahun & Produksi $(\mathrm{Kw})$ \\
\hline 1 & 2013 & 14.550 \\
2 & 2014 & 5.688 \\
3 & 2015 & 23.287 \\
4 & 2016 & 28.896 \\
\hline
\end{tabular}

Berdasarkan data tabel di atas menjelaskan bahwa produksi semangka dari tahun 2013 sampai tahun 2014 mengalami penurunan, namun dari tahun 2014 sampai tahun 2016 produksi semangka terus meningkat naik, hal ini diakibatkan oleh meningkatnya permintaan semangka di pasaran yang menyebabkan tingginya juga tingkat produksi yang dilakukan petani.

Kecamatan Banyuputih merupakan salah satu sentra penghasil semangka non biji yang cukup terkenal di Kabupaten Situbondo bagian timur. Semangka ini sangat cocok ditanam di daerah dataran rendah Kabupaten Situbondo. Petani semangka di Desa Sumberejo Kecamatan Banyuputih Kabupaten Situbondo belum dapat meningkatkan produksi secara optimal, salah satu penyebab adalah faktor cuaca, faktor produksi dan biaya produksi.

Produksi semangka yang semakin banyak belum tentu menghasilkan pendapatan yang semakin besar, karena harga semangka berpengaruh terhadap penerimaan. Harga semangka pada saat hari biasa masih stabil dan cenderung tinggi yaitu Rp 2.000 - Rp $3.500 / \mathrm{kg}$, namun pada saat awal musim panen raya harga buah semangka menjadi murah yaitu $\mathrm{Rp} 800$ - $\mathrm{Rp} 1.500 / \mathrm{kg}$, sehingga berpengaruh terhadap pendapatan petani semangka. Tanaman semangka non biji dibudidayakan sebanyak satu kali pada lahan sawah petani dalam kurun waktu satu tahun. Masa tanam dari tanaman ini dari proses pengolahan tanah sampai pasca panen, hanya membutuhkan waktu tiga bulan saja dengan hasil yang baik dan dijual dengan harga tinggi, sehingga menghasilkan pendapatan yang lebih tinggi dibandingkan dengan pendapatan dari usahatani lainnya. Akan tetapi, tanaman ini hanya diusahakan satu kali dalam setahun karena mempertimbangkan besarnya biaya yang harus dikeluarkan dalam usahatani tersebut sehingga tidak bisa memberikan kontribusi pendapatan petani setiap saat.

Berdasarkan latar belakang di atas, maka dilakukan penelitian dengan judul Analisa Kelayakan Usahatani Semangka Non Biji di Desa Sumberejo Kecamatan Banyuputih, dengan rumusan masalah sebagai berikut:

1. Berapa besar pendapatan usahatani semangka non biji di Desa Sumberejo Kecamatan Banyuputih?

2. Bagaimana tingkat efisiensi usahatani semangka non biji di Desa Sumberejo Kecamatan Banyuputih?

3. Bagaimana tingkat kelayakan usahatani semangka non biji di Desa Sumberejo Kecamatan Banyuputih?

\section{METODE PENELITIAN}

\section{Tempat dan Waktu Penelitian}

Penentuan daerah penelitian dilakukan secara sengaja (Purposive Method) yang dilaksanakan di Desa Sumberejo Kecamatan Banyuputih Kabupaten Situbondo. Lokasi ini dipilih atas pertimbangan sebagai berikut :

1. Desa Sumberejo Kecamatan Banyuputih merupakan salah satu wilayah di Kabupaten Situbondo yang petaninya masih intensif setiap tahunnya menanam semangka non biji. 
2. Terdapat 28 petani yang melakukan usahatani semangka non biji di Desa Sumberejo Kecamatan Banyuputih sehingga mempermudah peneliti untuk penentuan sampel.

3. Daerah lain di kawasan Kabupaten Situbondo bagian timur pada waktu penelitian masih belum ada desa yang mempunyai usahatani semangka non biji.

Waktu penelitian yang digunakan oleh peneliti pada bulan September 2018 sampai bulan Oktober 2018

\section{Teknik Pengumpulan Data}

Pengumpulan data adalah suatu usaha sadar untuk mengumpulkan data yang dilakukan secara sistematis, dengan prosedur yang terstandar (Arikunto, 2006). Bila dilihat dari sumber datanya, maka metode pengumpulan data yang dilakukan dalam penelitian ini dapat menggunakan sumber primer dan sumber sekunder.

1. Sumber data primer

Yaitu sumber data yang langsung memberikan data penelitian kepada pengumpul data. Untuk memperolehnya maka pengumpul data memperolehnya dengan cara:

a. Observasi

Yaitu suatu bentuk penelitian yang dilakukan penulis dengan pengamatan baik secara berhadapan langsung maupun secara tidak langsung seperti memberikan daftar pertanyaan untuk dijawab.

b. Wawancara

Yaitu yaitu penelitian dengan mengadakan wawancara secara langsung terhadap petani semangka non biji yang berhubungan dengan penelitian untuk mencari pendapatan, efisiensi, kontribusi dan faktor yang mempengaruhi pendapatan usahatani semangka non biji.

c. Dokumentasi

Yaitu penelitian yang dilakukan dengan jalan mengumpulkan catatan- catatan usahatani semangka non biji yang berhubungan dengan penelitian.

2. Sumber data sekunder

Yaitu sumber data yang tidak langsung memberikan data penelitian kepada pengumpul data, misalnya lewat orang lain atau dokumen. Untuk memperolehnya maka pengumpul data memperolehnya dengan cara membaca beberapa buku literatur-literatur, mengumpulkan dokumen, arsip, maupun catatan penting organisasi yang ada hubungannya dengan permasalahan penulisan skripsi ini dan selanjutnya diolah kembali

\section{Teknik Analisis Data}

Analisis data adalah metode yang digunakan untuk memperoleh data hasil penelitian, sehingga didapatkan suatu kesimpulan yang dapat dipertanggung jawabkan. Data yang diperoleh dalam penelitian ini disajikan dalam bentuk uraian dan angka. Pengolahan data dilakukan dengan analisis pendapatan dan R/C Ratio.

1. Untuk hipotesa yang pertama yaitu mengetahui bagaimana pendapatan usahatani semangka non biji di Desa Sumberejo Kecamatan Banyuputih digunakan rumus pendapatan sebagai berikut:

$$
\pi=\mathrm{TR}-\mathrm{TC}
$$

Keterangan :

$$
\begin{array}{ll}
\pi & =\text { Besarnya Tingkat Pendapatan } \\
\text { TR } & =\text { Total Penerimaan } \\
\text { TC } & =\text { Total Biaya Produksi (Soekartawi, 2011) }
\end{array}
$$


$\mathrm{TR}=\mathrm{P} . \mathrm{Q}$

Keterangan :

$\mathrm{TR}=$ Total Penerimaan

$\mathrm{P} \quad=$ Harga Produk

Q = = Jumlah Produksi (Soekartawi, 2011)

$\mathrm{TC}=\mathrm{TFC}+\mathrm{TVC}$

Keterangan :

TC $=$ Total Biaya Produksi

TFC = Total Biaya Tetap

TVC = Total Biaya Variabel (Soekartawi, 2011)

2. Untuk hipotesa yang kedua yaitu mengetahui efisiensi usahatani semangka non biji di Desa Sumberejo Kecamatan Banyuputih yang diusahakan efisien atau tidak, maka diperoleh dengan analisis berikut :

$\mathrm{R} / \mathrm{C}$ Ratio $=\mathrm{TR} / \mathrm{TC}$

Dimana : $\quad$ TR $\quad=$ Total Penerimaan

Jika :

$\mathrm{TC}=$ Total Biaya Produksi

R/C Ratio > 1, maka usahatani semangka non biji efisien

$\mathrm{R} / \mathrm{C}$ Ratio $=1$, maka usahatani semangka non biji impas

$\mathrm{R} / \mathrm{C}$ Ratio $<1$, maka usahatani semangka non biji tidak efisien

(Soekartawi, 2011)

3. Untuk hipotesa yang ketiga yaitu mengetahui kelayakan usahatani semangka non biji di Desa Sumberejo Kecamatan Banyuputih yang diusahakan layak atau tidak, maka diperoleh dengan analisis berikut :

$\mathrm{B} / \mathrm{C}$ Ratio $=\pi / \mathrm{TC}$

Dimana : $\quad \pi \quad=$ Total Pendapatan

$\mathrm{TC} \quad=$ Total Biaya Produksi

Jika :

a. Bila B/C > 1 maka setiap satu rupiah biaya yang dikeluarkan akan menghasilkan keuntungan lebih besar dari satu rupiah/ layak

b. Bila B/C $\leq 1$ maka setiap satu rupiah biaya yang dikeluarkan akan menghasilkan keuntungan sama/lebih kecil dari satu rupiah (Soekartawi, 2011)

\section{HASIL DAN PEMBAHASAN}

Penerimaan merupakan semua hasil yang diperoleh dari proses produksi, dimana total penerimaan petani semangka non biji dapat diketahui dengan cara melihat sumbersumber penerimaan petani, adapun sumber penerimaan petani semangka non biji musim tanam I dan II yaitu penjualan semangka non biji yang dijual petani. Setelah hasil produksi dan harga jual diketahui maka selanjutnya akan diuraikan besarnya penerimaan petani semangka non biji di Desa Sumberejo pada Tabel berikut.

Tabel 2. Penerimaan Usahatani Semangka Non Biji Musim Tanam I (2017) dan Musim Tanam II (2018) Perhektar Di Desa Sumberejo Kecamatan Banyuputih Kabupaten Situbondo

\begin{tabular}{cccc}
\hline \multirow{2}{*}{ Ket } & Produksi & Harga & Penerimaan \\
\cline { 2 - 4 } & $(\mathrm{Kg})$ & $(\mathrm{Rp})$ & $(\mathrm{Rp})$ \\
\hline MT I & 40.668 & 1.600 & 65.068 .569 \\
MT II & 43.482 & 2.000 & 86.964 .571 \\
\hline Rata-rata & 42.075 & 1.800 & 76.016 .570 \\
\hline
\end{tabular}

Sumber : Data primer diolah 
Berdasarkan Tabel, dapat diketahui bahwa penerimaan rata-rata usahatani semangka non biji musim tanam II tahun 2018 penerimaan rata-rata mencapai Rp 86.964.571,-. Penerimaan tersebut diperoleh dari penerimaan petani semangka non biji rata-rata di Desa Sumberejo selama satu musim tanam tahun 2018 perhektar yang bervariasi dari responden, dimana jumlah produksi semangka non biji rata-rata sebanyak $43.482 \mathrm{~kg}$ yang diperoleh petani dengan harga jual rata-rata sebesar Rp. 2.000,/kg. Besaran penerimaan yang diperoleh dari petani semangka non biji didapat dari hasil produksi semangka non biji dikalikan harga jual dipasaran.

Sedangkan penerimaan usahatani semangka non biji rata-rata dari kedua musim tersebut mencapai Rp 76.016.570,-. Penerimaan tersebut diperoleh dari penerimaan petani semangka non biji rata-rata dari kedua musim tersebut, dimana jumlah produksi semangka non biji rata-rata dari kedua musim tersebut sebanyak $42.075 \mathrm{~kg}$ yang diperoleh petani dengan harga jual rata-rata dari kedua musim tersebut sebesar Rp. $1.800, / \mathrm{kg}$. Besaran penerimaan yang diperoleh dari petani semangka non biji didapat dari hasil produksi semangka non biji dikalikan harga jual dipasaran rata-rata dari kedua musim tersebut.

Dapat disimpulkan bahwa penerimaan usahatani semangka non biji di Desa Sumberejo pada musim tanam I (2017) dan musim tanam II (2018) dihasilkan nilai penerimaan lebih besar pada musim tanam II yaitu pada tahun 2018. Hal tersebut terjadi disebabkan oleh lebih tingginya produksi dan harga jual semangka non biji pada musim tanam II daripada musim tanam I. Tingginya produksi pada musim tanam II karena tanaman yang terserang hama penyakit sedikit serta tidak musim tanam tidak turun hujan, sedangkan pada musim tanam I pada saat penanaman bertepatan dengan turun hujan pada pertengahan tanam sehingga hama dan penyakit meningkat pada tanaman. Pada musim tanam II harga tinggi karena bertepatan dengan hari besar seperti Maulid Nabi sehingga kebutuhan meningkat dan harga lebih tinggi.

\section{Biaya Produksi Usahatani Semangka Non Biji}

Biaya produksi merupakan sejumlah biaya yang dikeluarkan oleh petani dalam kegiatan produksi, komponen biaya adalah salah satu faktor yang perlu mendapat perhatian bagi setiap pelaku ekonomi, termasuk usahatani semangka non biji. Pada usaha pertanian semangka non biji, biaya yang dikeluarkan oleh petani terdiri atas biaya tetap dan biaya variabel.

Biaya total merupakan biaya yang diperoleh dari hasil biaya tetap dan biaya variabel yang dikeluarkan oleh petani semangka non biji. Biaya total merupakan biaya yang dikeluarkan oleh para petani untuk meningkatkan efisiensi dan pada akhirnya memberikan keuntungan yang lebih besar kepada para petani. Adapun total biaya yang dikeluarkan oleh petani semangka non biji di Desa Sumberejo Kecamatan Banyuputih dapat dilihat pada Tabel berikut. 
Tabel 3. Total Biaya Rata-rata Usahatani Semangka Non Biji Musim Tanam 1 (2017) dan Musim Tanam 2 (2018) Perhektar Di Desa Sumberejo Kecamatan Banyuputih Kabupaten Situbondo

\begin{tabular}{rrr}
\hline \multicolumn{1}{c}{ Keterangan } & $\begin{array}{r}\text { Musim Tanam 1 } \\
(\mathrm{Rp})\end{array}$ & $\begin{array}{r}\text { Musim Tanam 2 } \\
(\mathrm{Rp})\end{array}$ \\
\hline Biaya Tetap & & 14.906 \\
$\bullet \quad$ Pajak & 14.906 & 541.602 \\
- Penyusutan Alat & 498.791 & 556.508 \\
Total Biaya Tetap & 513.697 & \\
Biaya Variabel & & 4.375 .000 \\
• Biaya Faktor Produksi & & 3.295 .300 \\
1. Benih & 4.250 .016 & 3.017 .841 \\
2. Mulsa & 2.833 .958 & 2.263 .981 \\
3. Pupuk & 3.017 .842 & 12.952 .122 \\
4. Pestisida & 2.105 .502 & 6.343 .753 \\
$\quad$ Jumlah & 12.207 .318 & 19.295 .875 \\
Biaya Tenaga Kerja & 6.005 .488 & 19.852 .383 \\
\hline Total Biaya Variabel & 18.212 .806 & \\
Total Biaya & 18.726 .503 & 19.289 .443 \\
\hline Rata-rata Kedua Musim & \multicolumn{3}{c}{} \\
\hline
\end{tabular}

Sumber : Data primer diolah

Pada tabel, dapat diketahui bahwa jumlah total biaya rata-rata usahatani semangka non biji musim tanam II tahun 2018 di Desa Sumberejo dapat diketahui bahwa jumlah total biaya rata-rata usahatani semangka non biji musim tanam II perhektar di Desa Sumberejo mencapai Rp. 19.852.383,-- Total biaya tersebut diperoleh dari jumlah biaya tetap dan biaya variabel petani semangka non biji selama satu musim yang bervariasi dari keseluruhan petani responden, dimana rata-rata total biaya tetap yang diperoleh selama satu musim perhektar adalah sebesar Rp. 556.508,- yang dikeluarkan oleh seluruh petani semangka non biji di Desa Sumberejo, sedangkan rata-rata total biaya variabel perhektar yang dikeluarkan selama satu musim adalah sebesar Rp. 19.295.875,- yang dikeluarkan oleh seluruh petani semangka non biji di Desa Sumberejo.

Sedangkan total biaya usahatani semangka non biji rata-rata dari kedua musim di Desa Sumberejo mencapai Rp. 19.289.443,-- Total biaya rata-rata tersebut diperoleh dari biaya tetap dan biaya variabel rata-rata dari kedua musim tanam yang dilakukan petani semangka non biji di Desa Sumberejo.

Dapat disimpulkan bahwa total biaya usahatani semangka non biji di Desa Sumberejo pada musim tanam I (2017) ddan musim tanam II (2018) dihasilkan jumlah total biaya yang lebih besar dikeluarkan oleh petani berada pada musim tanam II yaitu pada tahun 2018. Hal tersebut terjadi disebabkan oleh lebih tingginya total biaya yang dikeluarkan petani pada musim tanam II daripada musim tanam I untuk melakukan usahatani semangka non biji baik dari biaya tetap maupun biaya variabel pada lahan tanam yang sama milik petani. Tingginya biaya pada musim tanam II karena harga sarana produksi dipasaran naik seperti benih, mulsa dan pestisida. Selain itu jumlah penggunaan juga ditingkatkan meskipun tidak terlalu banyak, hal tersebut dirasa perlu dilakukan oleh petani untuk meningkatkan hasil yang diperoleh dari usahatani semangka.

\section{Pendapatan Usahatani Semangka Non Biji}

Pendapatan diperoleh dari perhitungan selisih antara penerimaan dan biaya produksi. Jika nilai yang diperoleh adalah positif maka usaha tersebut memperoleh pendapatan dan jika nilai yang diperoleh adalah negatif maka usaha tersebut mengalami kerugian maka untuk memperoleh pendapatan maka jumlah penerimaan harus lebih besar dari total biaya (Soekartawi, 2011). Adapun besarnya pendapatan petani semangka 
non biji di Desa Sumberejo Kecamatan Banyuputih Kabupaten Situbondo dapat dilihat pada Tabel berikut.

Tabel 4. Pendapatan Usahatani Semangka Non Biji Musim Tanam I (2017) dan Musim Tanam II (2018) Perhektar Di Desa Sumberejo Kecamatan Banyuputih Kabupaten Situbondo

\begin{tabular}{cccc}
\hline \multirow{2}{*}{ Ket } & Penerimaan & Total Biaya & Pendapatan $(\pi)$ \\
\cline { 2 - 4 } & $(\mathrm{Rp})$ & $(\mathrm{Rp})$ & $(\mathrm{Rp})$ \\
\hline MT I & 65.068 .569 & 18.726 .503 & 46.342 .067 \\
MT II & 86.964 .571 & 19.852 .383 & 67.112 .189 \\
\hline Rata-rata & 76.016 .570 & 19.289 .443 & 56.727 .128 \\
\hline Sumber : Data primer diolah & &
\end{tabular}

Sumber : Data primer diolah

Berdasarkan tabel, dapat diketahui bahwa pendapatan rata-rata usahatani semangka non biji musim tanam II tahun 2018 di Desa Sumberejo mencapai Rp. 67.112.189,-. Pendapatan tersebut diperoleh dari pengurangan penerimaan dengan jumlah total biaya keseluruhan petani pada musim tanam II perhektar di Desa Sumberejo, dimana penerimaan rata-rata yang diperoleh keseluruhan petani perhektar sebesar Rp. 86.964.571,- yang diterima oleh seluruh petani semangka non biji. Sedangkan total biaya rata-rata yang dikeluarkan seluruh petani perhektar sebesar Rp. 19.852.383,- yang dikeluarkan oleh seluruh petani semangka non biji.

Sedangkan pendapatan usahatani semangka non biji rata-rata dari kedua musim tersebut mencapai Rp 56.727.128,-. Pendapatan tersebut diperoleh dari pengurangan penerimaan dengan jumlah total biaya petani semangka non biji rata-rata dari kedua musim tersebut perhektar di Desa Sumberejo, dimana penerimaan rata-rata dari kedua musim tersebut perhektar sebesar Rp. 76.016.570,-. Sedangkan total biaya rata-rata dari kedua musim tersebut perhektar sebesar Rp. 19.289.443,- yang dikeluarkan oleh seluruh petani semangka non biji. Pendapatan adalah hasil keuntungan bersih yang diterima petani yang merupakan selisih antara penerimaan dan biaya produksi.

Dapat disimpulkan bahwa pendapatan usahatani semangka non biji di Desa Sumberejo pada musim tanam I (2017) ddan musim tanam II (2018) dihasilkan jumlah pendapatan yang lebih besar diterima oleh petani berada pada musim tanam II yaitu pada tahun 2018. Hal tersebut terjadi disebabkan oleh lebih tingginya pendapatan yang diterima petani pada musim tanam II daripada musim tanam I untuk melakukan usahatani semangka non biji, sebab dari kedua musim tersebut nilai penerimaan usahatani semangka non biji lebih tinggi pada musim tanam II karena produksi dan harga jual semangka tinggi sedangkan total biaya yang dikeluarkan hanya memiliki selisih yang tidak terlalu besar.

\section{Efisiensi Usahatani Semangka Non Biji}

Return cost ratio adalah suatu usaha untuk mengetahui tingkat efisiensi dari suatu kegiatan yang dilakukan oleh petani. Suatu usaha dinyatakan efisien atau masih dalam tingkat layak bila nilai $\mathrm{R} / \mathrm{C}$ ratio bila lebih dari satu, semakin besar nilai $\mathrm{R} / \mathrm{C}$ ratio semakin besar tingkat efisiensinya. Analisa R/C Ratio usahatani semangka non biji adalah analisa untuk mengetahui efisiensi usahatani semangka non biji efisien atau tidak. 
Tabel 5. R/C Ratio Rata-rata Usahatani Semangka Non Biji Musim Tanam I (2017) dan Musim Tanam II (2018) Perhektar Di Desa Sumberejo Kecamatan Banyuputih Kabupaten Situbondo

\begin{tabular}{lc}
\hline \multicolumn{1}{c}{ Keterangan (Rata-rata) } & Nilai \\
\hline MT I & 3,47 \\
MT II & 4,38 \\
\hline Rata-rata & 3,93 \\
\hline
\end{tabular}

Sumber : Data primer diolah

Berdasarkan Tabel, diketahui bahwa efisiensi rata-rata usahatani semangka non biji pada musim tanam II perhektar berdasarkan penghitungan R/C Ratio di Desa Sumberejo mencapai 4,38. Sedangkan efisiensi usahatani semangka non biji rata-rata dari kedua musim tersebut perhektar berdasarkan penghitungan R/C Ratio di Desa Sumberejo mencapai 3,93. Sedangkan usahatani semangka non biji rata-rata dari kedua musim tersebut di Desa Sumberejo Kecamatan Banyuputih efisien dan menguntungkan untuk diusahakan. Faktor pendorong yang mengakibatkan R/C Ratio usahatani semangka non biji rata-rata dari kedua musim tersebut efisien sampai 3,93 adalah besarnya penerimaan yang diperoleh, harga semangka non biji yang cukup tinggi serta jumlah produksi semangka non biji yang relatif tinggi sehingga menyebabkan tingginya penerimaan usahatani semangka non biji rata-rata dari kedua musim tersebut. Maka setiap penambahan 1 rupiah biaya yang dikeluarkan untuk melakukan usahatani semangka non biji rata-rata dari kedua musim tersebut akan menghasilkan penerimaan usaha sebesar Rp. 3,93,-.

Dapat disimpulkan bahwa efisiensi usahatani semangka non biji di Desa Sumberejo pada musim tanam I (2017) ddan musim tanam II (2018) dihasilkan jumlah efisiensi yang lebih besar berada pada musim tanam II yaitu pada tahun 2018. Hal tersebut terjadi disebabkan oleh nilai penerimaan usahatani semangka non biji lebih tinggi pada musim tanam II karena produksi dan harga jual semangka tinggi sedangkan total biaya yang dikeluarkan hanya memiliki selisih yang tidak terlalu besar

Usahatani semangka non biji memiliki nilai R/C Ratio sangat besar artinya bertanam semangka dapat memberikan keuntungan yang besar apabila di tanam yang tepat yaitu saat permintaan tinggi di Situbondo dan biasanya pada saat musim kemarau, namun demikian perlu kiranya petani harus mempersiapkan pemasaran dengan baik. Pada saat panen raya terjadi penurunan harga semangka sehingga petani merugi, petani perlu memahami kapan harus menanam komoditi ini, mengingat umur panennya yang sangat singkat (58-60 hari).

\section{Kelayakan Usahatani Semangka Non Biji}

Soekartawi (2011), menyatakan bahwa analisis ratio keuntungan atas biaya (B/C Ratio) merupakan salah satu cara untuk mengetahui perbandingan antara keuntungan dan biaya yang dikeluarkan. Analisis B/C Ratio digunakan untuk mengetahui kelayakan usahatani semangka non biji yang ada di Desa Sumberejo sehingga peneliti mengetahui apakah usaha tersebut layak untuk dikembangkan

Untuk hipotesa yang ketiga yaitu agar dapat mengetahui kelayakan usahatani semangka non biji layak atau tidak tidak untuk dikembangkan di masa yang akan datang maka diperoleh melalui analisis B/C ratio yaitu pembagian antara total pendapatan (Benefit) dan total biaya (Cost). Untuk analisis tersebut dapat dilihat pada tabel di bawah ini 
Tabel 6. B/C Ratio Rata-rata Usahatani Semangka Non Biji Musim Tanam I (2017) dan Musim Tanam II (2018) Perhektar Di Desa Sumberejo Kecamatan Banyuputih Kabupaten Situbondo

\begin{tabular}{ll}
\hline \multicolumn{1}{c}{ Keterangan (Rata-rata) } & Nilai \\
\hline MT I & 2,47 \\
MT II & 3,38 \\
\hline Rata-rata & 2,93 \\
\hline
\end{tabular}

Sumber : Data primer diolah

Berdasarkan Tabel, diketahui bahwa kelayakan rata-rata usahatani semangka non biji pada musim tanam I perhektar berdasarkan penghitungan B/C Ratio di Desa Sumberejo mencapai 2,47. Kelayakan rata-rata usahatani semangka non biji pada musim tanam II perhektar berdasarkan penghitungan B/C Ratio di Desa Sumberejo mencapai 3,38. Sedangkan kelayakan usahatani semangka non biji rata-rata dari kedua musim tersebut perhektar berdasarkan penghitungan B/C Ratio di Desa Sumberejo mencapai 2,93 .

Maka dapat disimpulkan bahwa usahatani semangka non biji rata-rata dari kedua musim tersebut di Desa Sumberejo Kecamatan Banyuputih layak untuk diusahakan. Faktor pendorong yang mengakibatkan B/C Ratio usahatani semangka non biji rata-rata dari kedua musim tersebut layak sampai 2,93 adalah besarnya pendapatan yang diperoleh, harga semangka non biji yang cukup tinggi serta jumlah produksi semangka non biji yang relatif tinggi sehingga menyebabkan tingginya pendapatan usahatani semangka non biji. Maka setiap penambahan 1 rupiah biaya yang dikeluarkan untuk melakukan usahatani semangka non biji rata-rata dari kedua musim tersebut akan menghasilkan keuntungan usaha sebesar Rp. 2,93,-.

\section{KESIMPULAN}

Berdasarkan hasil penelitian kelayakan usahatani semangka non biji di Desa Sumberejo Kecamatan Banyuputih Kabupaten Situbondo untuk mengetahui pendapatan dan tingkat kelayakan usahatani semangka non biji dapat disimpulkan sebagai berikut :

1. Pendapatan rata-rata usahatani semangka non biji rata-rata selama dua musim terakhir pada tahun 2017 dan 2018 di Desa Sumberejo Kecamatan Banyuputih menguntungkan, dimana pendapatan rata-rata dari kedua musim tersebut mencapai Rp. 56.727.128,--

2. Efisiensi untuk usahatani semangka non biji rata-rata dari kedua musim tersebut berdasarkan analisis R/C Ratio yang dilakukan di Desa Sumberejo Kecamatan Banyuputih efisien untuk dikembangkan. Dimana efisiensi rata-rata dari kedua musim tersebut mencapai 3,93.

3. Kelayakan untuk usahatani semangka non biji rata-rata dari kedua musim tersebut berdasarkan analisis B/C Ratio yang dilakukan di Desa Sumberejo Kecamatan Banyuputih layak untuk dikembangkan. Dimana kelayakan rata-rata dari kedua musim tersebut mencapai 3,93.

\section{REFERENSI}

Anonim. 2016. Kabupaten Situbondo Dalam Angka 2016. BPS Kabupaten Situbondo. Situbondo.

Anonim. 2017. Laporan Kinerja Direktorat Jenderal Hortikultura 2016. Jakarta

Arikunto. 2006. Prosedur Penelitian Suatu Pendekatan Praktek. Rineka Cipta. Jakarta 
Dumairy. 2007. Perekonomian Indonesia. Erlangga. Jakarta

Moehar, D. 2002. Pengantar Ekonomi Pertanian. PT Bumi Akasara. Jakarta

Soekartawi. 2011. Analisis Usahatani. Penerbit Universitas Indonesia. Jakarta

Soetriono, dkk. 2006. Pengantar Ilmu Pertanian. Bayu Media. Jember. 